\title{
Representações sociais sobre o consumo de açúcar no dia a dia
}

\section{Social representations about daily sugar consumption}

Giovana Duarte dos Santos ${ }^{1}$

À medida em que somos levados a refletir sobre algum de nossos hábitos alimentares é onde percebemos tê-lo. O consumo de açúcar está presente no cotidiano e enraizado nos hábitos alimentares dentro de um contexto urbano, seja pela facilidade de encontrar produtos industrializados, seja pelo hábito social das bebidas açucaradas ou somente pelo gosto. De acordo com o artigo de Levy e colaboradores sobre a disponibilidade de "açúcares de adição" no Brasil, existem dois tipos de açúcares: aqueles encontrados naturalmente nos alimentos, como a frutose e a sacarose presentes nas frutas e a lactose presente no leite, e aqueles extraídos de alimentos (cana-de-açúcar, beterraba e milho) para uso posterior em preparações culinárias ou na elaboração de alimentos processados.

Para compreender melhor como percebemos o consumo de açúcar no dia a dia, foram realizadas dez entrevistas com indivíduos de classe média que vivem em cidades da Grande São Paulo e sempre viveram em São Paulo, sendo três mulheres e sete homens. Cinco possuíam o segundo grau completo e cinco o superior completo. A idade variou de 23 a 55 anos. A coleta de dados ocorreu entre agosto e setembro de 2019 quando os entrevistados responderam à questão que norteou a pesquisa: "Como é o seu consumo de açúcar no dia a dia?".

Para a análise dos discursos foi utilizado o conceito de representações sociais de Moscovici tendo como objetivo compreender como as informações sobre o açúcar são incorporadas pelo indivíduo de modo que essas ideias interajam no seu cotidiano em seus costumes e valores, ajudando a compor sua identidade. Foi também observado como o indivíduo utiliza esses conceitos teóricos como balizadores de suas práticas alimentares, adotando um discurso ora permissivo ora não para justificar suas escolhas e hábitos alimentares.

A pesquisa procurou traçar paralelos entre as entrevistas e dados obtidos sobre o consumo de açúcar do brasileiro de classe média que vive em ambientes urbanos para contextualizar os discursos e suas realidades.

A associação do consumo de açúcar a doenças como o diabetes foi um ponto bastante citado quanto à questão de saúde, porém em alguns casos era identificado como fatores causais o pão e arroz, assumindo a representação que o indivíduo faz do que é o açúcar. Por outro lado, as frutas continham o açúcar que era "bom" para a saúde. Segundo Laplantine, em a Antropologia da Doença (1991), temos a tendência de classificar os alimentos em "bons" ou "maus", e assim fazemos com o açúcar. O consumo de açúcar do brasileiro é de 16,7\% do total de calorias diárias, muito acima do que a Organização Mundial de Saúde estipula, de 10\%. As representações sociais sobre o consumo de açúcar no dia a dia podem promover algumas reflexões sobre propostas de educação alimentar tanto na esfera de políticas púbicas de saúde quanto no individual. 
Palavras-chave: representações sociais; açúcar; hábitos alimentares.

Keywords: social representations; sugar; eating habits.

1 Pós-graduanda em Gastronomia: História e Cultura no Centro Universitário Senac, em São Paulo. 